\title{
Revealing The Pictures of Research Culture In Vietnamese Higher Education Institutions
}

\author{
Nguyen Hoang Thien ${ }^{a}$ \\ Ho Chi Minh City University of Education
}

\begin{abstract}
This article aims to reveal the features of research culture in Vietnamese universities, through various indicators. It shows that among factors impacting the formation of research culture in Vietnamese universities are state-related ones, including policies, regulations, norms and traditions for university research. The state-related factors have contributed to bettering the qualifications of lecturers, recognizing faculty's research works with financial and non-financial rewards, strengthening the cooperation between universities with external research partners, and increasing the number of publications. Yet, at the same time, different problems stem from the existence of some state-related factors including the nation's tradition of spending less on higher education than on basic education and less on universities than on research institutes, the lack of autonomy among universities, the almost ultimate power of the university rector, and the use of the historically-negotiated recurrent approach for allocating research funding to universities. Given the fact that Vietnam's higher education is highly regulated by the state, changes to research culture in universities must accompany changes to the state-related factors believed to influence the formation of research culture.
\end{abstract}

Keywords: university research, research culture, state-related factors, regulations, traditions

\section{Introduction}

Research is one of the significant missions of universities, and generally, it is also one of the obligations of university faculty, in addition to teaching and serving the community (Center for Postsecondary Research, 2015). By and large, universities in developed countries have a long-established record of research, while the majority of those in developing countries focus more on teaching activities, and as a consequence, remain frail in terms of research (Sanyal \& Varghese, 2006). Concerning Vietnam, research in the country used to be supported and controlled by the government mainly through a few hundred public research institutes that operated independently of higher education institutions, following the Soviet model (Nguyen, 2013). Since the 1990s, the government has encouraged universities to enhance their research capacity, which has been exhibited in various policies and activities (Nguyen, 2016). In 2005, the Ministry of Education and Training (MOET) launched the 2006-2020 Higher Education Reform Agenda (Pham, 2010). This agenda is the strategy and ambition of the government in making changes to help the higher education system in Vietnam develop, some of which included the formation of a tier of "research-oriented" universities, and a critical increment in the number of academics with doctoral degrees. This agenda highlighted the requirement for a more grounded pledge of research as well (Le \& Hayden, 2017). In 2013 the first law on higher education in Vietnam took effect (National Assembly of Vietnam, 2012), marking one of the milestones in Vietnam's higher education. Higher Education Law is another policy document that has effects on research in Vietnamese higher education institutions (Nguyen, 2020). This law reinforces what was highlighted in the 2006-2020 Higher Education Reform Agenda about the requirement for Vietnam to have a group of universities eligible for attaining international rankings. As regulated by the law, components are applied to help enhance research performance inside higher

a Correspondence can be directed to: hoangthien@ier.edu.vn 
education organizations, such as providing funding and different awards to academics with research published in peer-reviewed international journals (Pham \& Hayden, 2019). It also strengthens the requirement for more institutional autonomy through the establishment of governing boards, known as university councils (Hoi dong Dai hoc) in the case of public universities (Le \& Hayden, 2017). This is a significant premise and a legal basis for the decrease of state regulation, which is expected to help universities, especially public ones, to be more autonomous in how they are run, with the authority to make decisions and be responsible for their different activities, including research (UNESCO, 2014).

Among various ways of understanding the research aspect of universities are cultural approaches. Cultural analysis can help improve the administrative action of organizations (Austin, 1990) and can result in a deep understanding of organizations, governance, and working life (Hurtado et al., 2012). However, research culture and other cultural matters that lead to the improvement or deterioration of research productivity in certain educational contexts are paid scant attention (SalazarClemeña \& Almonte-Acosta, 2007). Culture forms from rules, beliefs, customs, and assumptions of members of an organization, becoming a collective activity or a system of shared meaning (Deem \& Lucas, 2007; Morgan, 2006; Robbins \& Judge, 2006). The research culture of universities can be viewed in the same way. It is the common features found in the research aspect of the universities, which are made up of visible factors such as norms, rules and regulations, and less visible ones, such as customs, beliefs, and assumptions (Schein, 2010; Zha \& Shen, 2018). Among various factors, such as the economic and social conditions of the country and its national culture, the culture of a university is shaped and influenced by what the government does toward education, and how (Smerek, 2010; Lacatus, 2013). In the context of Vietnam, given the state's "over-centralized" control of higher education (London, 2011), the influence of the state in forming common features of research in universities is not only obvious but also likely to be tremendous. Therefore, studying Vietnamese higher education cannot ignore the state's role in this sector.

Several studies relate to the state's impacts on research culture in Vietnamese universities, such as the role of research committees (Salmi \& Pham, 2019; Pham, 2017), traditions of cooperation with external partners for research enhancement (Harman \& Nguyen, 2010; Spoo \& Dao, 2010), and the research status of Vietnamese universities, mainly through the quantity and quality of international articles produced (Nguyen, 2020; Trinh et al., 2020; Trung et al., 2020). However, although different aspects of research culture are mentioned sporadically in different studies, the literature lacks works that provide a comprehensive feature of research culture in Vietnamese universities. There is also a lack of research showing how the State influences and contributes to the formation of common characteristics of university research in Vietnam. This study will therefore connect the different aspects of research culture in Vietnamese universities as mentioned in different studies to form a systematic picture of such culture in Vietnamese higher education institutions. At the same time, this study will review what state-related factors have contributed to forming a research culture in Vietnamese universities. To reveal the reality of research culture in Vietnamese higher education institutions, this study aims to address two questions: "What are the features of research culture in Vietnamese universities?" and "What state-related factors have influenced the formation of these features?"

\section{Research Methodology and Analytical Framework}

This paper is developed based on the analysis of research on topics relevant to university research in Vietnam as well as government policies and regulations on university research, such as the 2006-2020 Higher Education Reform Agenda, the 2012 Higher Education Law, the Amendment of Higher Education Law 2018, the 2013 Law on Science and Technology, Project 322, Project 911, Project 89, and Decree 99/2014/ND-CP which introduces regulations on investment to develop science and technology potential of higher education institutions. The state of research culture in Vietnamese higher education institutions depicted here is mainly focused on public universities since they accounted for 172 out of 237 universities, not counting those in the security and defense 
sectors in the 2018-2019 academic year (MOET, 2019). Moreover, many private institutions generally appear to follow the practices of public universities instead of taking advantage of their autonomy in making decisions on various institutional matters. Thus, there are more similarities between these sectors of higher education in Vietnam than disparities (Salmi \& Pham, 2019).

Culture is a complex concept, so different researchers such as Smith, Dugan \& Trompenaars (1996), Steenkamp (2001), and Hofstede, Hofstede \& Minkov (2010) have tried to develop a framework to narrow it down while studying this theme and its related matters. Salazar-Clemeña and Almonte-Acosta (2007), while investigating the research culture of higher education institutions, also operationalize indicators of research culture from various researchers. In order to understand the research culture of Vietnamese universities, this study used the indicators introduced by SalazarClemeña and Almonte-Acosta (2007, p. 4) as a framework. These indicators were previously used to explore a similar topic in the Philippines, and also to study research-related matters at Mexican universities (Hernandez \& Reyes, 2014).

Although adopting this framework, this study integrated the dimension of "Departmental culture and working conditions" in the dimension of "Institutional research policies and agenda". As regulated by Vietnam's Higher Education Law of 2012, in Vietnamese public higher education institutions, many aspects classified by Salazar-Clemeña and Almonte-Acosta (2007) in the dimension of "Departmental culture and working conditions," such as giving faculty opportunities to improve and practice their research capacity and establishing criteria for recruiting academics (p. 4), are also part of the state and the university's general policy rather than of only departments themselves (National Assembly of Vietnam, 2012). These adapted indicators with specific aspects are provided in Table 1.

Table 1. The analytical framework of the research

\begin{tabular}{|c|c|}
\hline Indicators & Specific aspects \\
\hline $\begin{array}{l}\text { Institutional research policies } \\
\text { and agendas }\end{array}$ & $\begin{array}{l}\text { Research agendas of the universities, including programs and schemes } \\
\text { to incentivize and sustain research productivity among academics and } \\
\text { graduate students } \\
\text { Criteria for employing academics }\end{array}$ \\
\hline Budget for research & $\begin{array}{l}\text { The funds for research } \\
\text { The ability of the universities to attract external sources and get } \\
\text { research grants }\end{array}$ \\
\hline Infrastructure & The existence of various services and facilities to support research \\
\hline $\begin{array}{l}\text { Collaboration with and access to } \\
\text { research professionals in other } \\
\text { institutions }\end{array}$ & $\begin{array}{l}\text { The ability to offer ways of linking external partners such as other } \\
\text { institutions, experts, and firms to strengthen power for research } \\
\text { development }\end{array}$ \\
\hline $\begin{array}{l}\text { Policies and guidelines on } \\
\text { research benefits and incentives }\end{array}$ & $\begin{array}{l}\text { Regulations and procedures on the giving of rewards with financial and } \\
\text { non-financial value for research }\end{array}$ \\
\hline Research committee & $\begin{array}{l}\text { The body that checks the kinds of research undertaken and examines } \\
\text { moral matters involved }\end{array}$ \\
\hline Publications & $\begin{array}{l}\text { The quality and quantity of research conducted by the academics, } \\
\text { which can be evidenced in various aspects such as the quantity of } \\
\text { research published in journals. }\end{array}$ \\
\hline
\end{tabular}

Reference: Salazar-Clemeña \& Almonte-Acosta (2007)

After providing the highlights of university research mentioned in various studies and state documents, reflected through the indicators that Salazar-Clemeña and Almonte-Acosta (2007) provided, this study examines what state-related factors have influenced the formation of these features. 


\section{Research Culture in Vietnamese Universities}

\section{Institutional Research Policies and Agendas}

In helping higher education institutions improve the quality of academic staff, the state implemented Project 322 and Project 911, which were established in 2000 and 2010 respectively (The Prime Minister of Government, 2002, 2010), by awarding scholarships to lecturers participating in doctoral training programs abroad. In addition, in 2014, the government issued Decree 99/2014/ ND-CP, which guides universities in establishing strong research groups and funding for lecturers attending international conferences, among other things (The Prime Minister of Government, 2014). However, practical applications can have many variations. Nguyen (2016), in her work on managing human resources for research in four leading universities in Vietnam, indicated that when it comes to strategies for developing academics' research skills and ability, these institutions have been exceptionally enthused about overhauling academics' formal education. Yet, they have rarely provided expert advancement courses in this regard. These organizations also lack effective policies on appraising research execution, which weakens the incentive for academics to do research.

In financial terms, in Vietnam, a full-time lecturer is paid a base salary, and the Ministry of Home Affairs imposes pay scales for government employees, including permanent staff of public higher education institutions (Nguyen, 2016). On November 12, 2019, the National Assembly of Vietnam issued Decree 86/2019/QH14, which regulates the new salary for government staff including university lecturers in public institutions of higher education. This Decree was expected to take effect on July 01,2020 . The minimum salary of university lecturers was to slightly increase from the existing minimum of about 3,486,000 Vietnamese Dong (VND) (approximate to 151 US dollars [USD]) to 3,760,000 VND (approximate to 163 USD) (National Assembly of Vietnam, 2019). However, due to the effect of Covid-19 pandemic on the state's budget, the National Assembly postponed the implementation of the Decree until July 2022 (Communist Party of Vietnam Online Newspaper, 2020). For now, lecturers are receiving salaries based on the pay scales for government employees established in Decree 204/2004/ND-CP, issued in December 2004 (MOET, 2020b). While it is hard to gauge the total income that faculty members receive from different types of business, including part-time contracts, official information shows that pay rates in the domain of education and training in Vietnam for those with advanced educational qualifications are marginally lower than those in different areas (Le \& Hayden, 2017). However, in recent years, a number of universities have also had a reward program for staff with articles published in Scopus/Web of Science-indexed journals, with rewards much greater than the average monthly salary (Cao-Nguyen, 2019; Minh-Giang, 2019). Concerning graduate students, by and large, although doctoral students have to pay higher tuition fees than bachelor's and master's students, Vietnamese graduate programs provide them with almost no financial support system. Neither do they provide doctoral students with graduate assistantships, grants, credits, and the recognition of their work status (World Bank, 2020a). Ton Duc Thang University and Ho Chi Minh City International University (a member of Vietnam National University, Ho Chi Minh City) are rare cases of policies on scholarships for graduate students, in the form of tuition fee support, in which the highest scholarship is a $100 \%$ tuition reduction (Ho Chi Minh City International University, 2021; Ton Duc Thang University, 2021).

The Amendment of Higher Education Law 2018 emphasizes attracting, using, and treating human resources appropriately, to improve the quality of lecturers and develop them toward becoming doctoral degree holders, as well as leading professors in higher education institutions. This amendment also stipulates that higher education institutions will give priority to recruiting candidates with doctoral degrees as lecturers (National Assembly of Vietnam, 2018). Although policies exist to employ competent academics, research accomplishments are not always included in the criteria for recruitment in institutions. Some institutions also lack policies on welcoming outstanding overseas individuals (Nguyen, 2016; Pham \& Nguyen, 2020). In 2019, Project 89 was launched to train and improve the capacity of lecturers and managers of higher education institutions. Accordingly, the project aims to provide doctoral training for about $10 \%$ of university lecturers, of 
which $7 \%$ of lecturers are trained full-time abroad and $3 \%$ of lecturers are domestically trained in programs cooperated between Vietnamese and international universities that meet regional and international quality standards. Project 89 also aims to attract at least 1,500 scholars and individuals with doctoral qualifications to Vietnamese higher education institutions (The Prime Minister of Government, 2019). This new project is expected to address the limitations of previous ones in the sense that universities will not only have more staff with doctoral degrees but will also be able to attract and employ them after they complete their doctoral programs (Nguyen, 2020). Since this is a newly issued document, it will certainly require more time to be able to observe and assess its results in reality.

\section{Budget for Research}

In the Amendment of Higher Education Law 2018, the government emphasizes the allocation of budgets and resources to higher education on the principles of competition, equality, and efficiency, through a variety of forms, including research and development spending and ordering research projects from universities. The state also encourages and has preferential policies for organizations, businesses, and individuals to invest in science and technology activities at higher education institutions, such as tax exemptions and reductions (National Assembly of Vietnam, 2018). In reality, Vietnam has mainly focused on allocating high levels of its public resources to basic education, while higher education receives scant attention. In 2018 only $15.01 \%$ of public expenditure on education was allocated to the sector of higher education (Salmi \& Pham, 2019). Furthermore, the Vietnamese government contributed only $0.25 \%$ of its gross domestic product (GDP) to higher education, which is not adequate for the provision of quality teaching and research (Vo \& Laking, 2020). In addition, the budget for education and training on all levels has been cut gradually since 2017. For example, $14.20 \%$ of the country's budget expenditure was spent on all fields related to education and training in 2018, compared with $14.03 \%$ in 2019 (Pham-Nghia \& Quang-Duc, 2020).

In Vietnam, the Ministry of Science and Technology is responsible for allocating funding to research in universities after receiving money from the state (Nguyen \& Meek, 2016). Every year, the government invests about $2 \%$ of its budget in scientific research ( $0.5 \%$ of the GDP); however, the Ministry of Science and Technology only gets from 8 to $10 \%$ of this $2 \%$. Therefore, the real funding for scientific research at Vietnamese universities is very limited (Ngo \& Pham, 2019). The portion for university research is far less given that the amount of funding from the Ministry of Science and Technology is allocated not only to universities but also other institutes, and especially when much of the Ministry's research funding is preserved for government research institutes (World Bank, 2019; Nguyen, 2020). When measured per capita, the funding for each faculty member invested in scientific research is very small. At Vietnam National University, Ho Chi Minh City, one of the two national universities in Vietnam, a lecturer only receives a research grant of 16 million VND a year (approximate to 700 USD) (Ha-Anh, 2019). Although government spending on university research is limited, it is the principal financial source for research in universities since institutions of higher education in Vietnam attract insignificant funding from outside sources (Harman \& Nguyen, 2010; Salmi \& Pham, 2019).

Since universities are financially dependent on the government, the government is able to decide if the universities can successfully build their research capacity or not. The role of the government involves considerably raising the research budget, protecting the process of allocating funding from political scrutiny and intervention, and keeping funding steady over time (World Bank, 2020a). Another feature of the budget for research in Vietnam is that although Vietnam made the transition to a market economy (World Bank, 2020b), the old rules of the state-controlled economy are still the basis for research and development activities. The research of universities is closely "watched" by the university and state authority "to ensure consistency with the ideology and principles of socialism" (Vo \& Laking, 2020, p. 1095). Besides the fact that research topics must have "suitable" ideology and principles, researchers' use of the funding they receive is tightly supervised by their 
universities and the state (Ngo \& Pham, 2019). Moreover, "Vietnam still follows historically-negotiated recurrent budget allocation rather than the more objective and transparent formula-based funding or performance-based funding mechanisms that are increasingly used globally" (World Bank, 2019, p. 5). This means that the provision of yearly funding from the government for universities is based on previous years' allocation patterns rather than on universities' real demands and performance.

\section{Infrastructure}

Article 40 of the 2012 Higher Education Law states that institutions of higher education must build laboratories and research facilities to provide training and scientific research (National Assembly of Vietnam, 2012). Decree 99/2014/ND-CP also emphasizes the provision of facilities for research activities in Vietnamese universities, including building modern specialized laboratories and library systems, journals, information technology infrastructure and databases on science and technology; purchasing intellectual property and copyrights to access foreign science and technology databases; transferring and importing technology and supporting technology consistent with the law (The Prime Minister of Government, 2014). In compliance with other regulations issued, in the 2000s the state has invested in infrastructure development programs and some improvements to the infrastructure of the universities have been made (Le \& Hayden, 2017). However, this has not always been possible. In reality, many institutions must accommodate an increasing number of students but face difficulty in expanding their campuses, as they are located centrally in large cities that have almost no unoccupied land (World Bank, 2020a). With narrow premises and outdated equipment, it is very challenging for universities to better the quality of training and research (Le, 2015).

Likewise, the World Bank (2020a) reveals that current information and communication technology infrastructure systems in Vietnamese institutions are outdated, inefficient, and asynchronous. Moreover, there is a lack of high-performance computing facilities for supporting advanced research. Connections with VinaRen, the National Research and Education Network, are absent in many institutions, which prevents academics from linking with international research communities. Even national universities (Vietnam National University, Hanoi and Vietnam National University, Ho Chi Minh City), as well as regional universities including Hue University, the University of Danang, and Thai Nguyen University in Vietnam, have to face these issues although they have better laboratories, workshops, and equipment than many other institutions. Besides, it is not easy for faculty and students at Vietnamese universities, including their graduate research programs, to access the resources and facilities in key national laboratories. The fact that most of these laboratories are in Ho Chi Minh City and Hanoi, the law requires that individuals and organizations pay user fees. Yet most Vietnamese graduate programs do not have funding to support learners in research (The Ministry of Science and Technology, 2008; World Bank, 2020a). Access to resources such as books and magazines is also limited because university libraries not only have very limited resources but also lack a tradition of sharing resources with one another (Tran, Mai \& Luu, 2017). Furthermore, Pham (2018) found that only $10 \%$ of Vietnamese university libraries are linked to major international academic resources such as ScienceDirect or Elsevier. However, the infrastructure of universities is being upgraded by the state, universities themselves, and other stakeholders. For instance, the World Bank has financed a 295 million USD credit to fund modern infrastructure, cutting-edge equipment, and knowledge transfers at Vietnam National University-Hanoi, Vietnam National University-Ho Chi Minh City, and the University of Danang (World Bank, 2020b).

With respect to administrative support for research at universities, an examination in some Asian nations by Huang (2018) found that very few respondents in his research strongly agreed or agreed that the staff at their organizations provided them with support. Among the groups of participants, a huge extent of the individuals in China (60.6\%) and in Singapore (55.5\%) showed strong with the statement that their universities receive support from the staff. The percentage of participants from other countries and regions who had the same responses is less than $50 \%$, which includes Taiwan (48.4\%), Malaysia (46.2\%), Japan (45.6\%), and Cambodia (38\%). The proportion of 
respondents choosing "strongly agree" and "agree" in Vietnam is the least, at only $32.7 \%$. Likewise, Nguyen and Meek (2016) showed that the universities in their research have not professionalized their administration of research.

\section{Collaboration with and Access to Research Professionals in Other Institutions}

The ability to offer ways of linking to external partners to strengthen research development has gradually received attention from the government. Compared to the 2012 Higher Education Law, the Amendment of Higher Education Law 2018 added details related to collaboration in university research. The amendment encourages international cooperation and integration to develop Vietnam's higher education on regional and international levels (National Assembly of Vietnam, 2012, 2018). However, collaboration with institutions and experts in research is mainly reflected through publications (Nguyen, Ho-Le \& Le, 2017, Nguyen et al, 2020). The analysis of papers published in Web of Science-indexed journals from January 1, 2001, to December 31, 2015, shows that about $97 \%$ of the scientific publications from Vietnam are multiauthored by both national (domestic) and international scholars. However, the rate of national collaboration is only around $16 \%$ of the total output, whereas international collaboration makes up 77\% (Nguyen et al., 2017). This rate is high, compared to the average percentage of scientific output featured by international co-authors that Ribeiro, et al. (2018) calculated based on statistics of Web of Science-indexed papers in 2015, (21.3\%). Based on the number of articles in the field of social sciences and humanities published in Scopus/ Web of Science-indexed journals and journals recognized for quality by the National Foundation for Science and Technology Development (NAFOSTED), Nguyen et al. (2020) also conclude that international cooperation in scientific research via co-authoring in Vietnam increased from 2008 to 2018.

In 2013 the Law on Science and Technology was issued with regulations stating the obligations for transferring or using the results of scientific and technological activities of organizations and individuals in these fields. The Law also provides legal bases to incentivize technology transfer such as tax deductions and low loans for this activity (National Assembly of Vietnam, 2013). With the enforcement of this Law, research and development activities with the participation of different stakeholders are encouraged. Also, the Amendment of Higher Education Law 2018 stipulates that higher education institutions must promote cooperation with enterprises and science and technology organizations, and encourage agencies, organizations and enterprises to receive and create opportunities for learners and lecturers to practice scientific research and technology transfer (National Assembly of Vietnam, 2018). As a result, in addition to their team, businesses have gradually cooperated with experts and scientists at research institutes and universities to solve businessdevelopment problems (Ha-Linh, 2020). This reflects a change compared to about one decade ago when partnerships between businesses and Vietnamese institutions of higher education and research institutes were rare (Fatseas, 2010; Ca \& Hung, 2011). It is also worth noting that although academics have offered enterprises assistance with business development, there is generally a lack of funding for academic research from the business sector (Nguyen, 2020). Vietnam's higher education institutions lack close linkages, and its education, is still a "closed" system when it comes to collaborations with businesses. (Kunnari, Tien \& Nguyen, 2019).

\section{Policies and Guidelines on Research Benefits and Incentives}

Regarding rewards for research in universities, Decree 99/2014/ND-CP was issued in 2014, with regulations and guidelines on investment in developing science and technology in academic institutions, to help universities improve in this area (The Prime Minister of Government, 2014). This decree regulates investment contents in science and technology, such as human resources, spending on science and technology activities in higher education institutions (e.g., organizing conferences and seminars), and funding published articles in prestigious international scientific journals. According to 
this decree, lecturers, leading scientists, or talented young scientists will enjoy certain financial and non-financial priorities. For instance, academics who have an article published in a scientific journal that is rated at least 1 (the highest-ranking is 3 ) by the national body that grants professorship titles, the Hoi dong Chuc danh Giao su Nha nuoc, receives a teaching credit of 20 hours. Apart from that, MOET has decided to reward individuals from institutions it manages, who have articles published in Web of Science-indexed journals. As a result of this decision, MOET spent more than 6.1 billion VND (approximate to 260,000 USD) in 2018, on the authors of 1,718 articles published in Web of Science-indexed journals. The minimum award for an article was 2 million VND (approximate to 86 USD) (Han-Tran, 2019). In 2020, up to 10.8 billion VND (approximate 468,000 USD) was awarded to the authors of 3,627 articles published in such journals (Minh-Giang, 2021).

Some universities have implemented these guidelines with consideration of their financial situations and development strategies. For example, Ho Chi Minh City University of Economics has announced a maximum grant of 200 million VND (approximate to 8,600 USD) for a Scopus/Web of Science-indexed article (Minh-Giang, 2019). This amount at Ho Chi Minh City University of Technology and Education and Ho Chi Minh City Open University is 100 million VND (approximate to 4,300 USD) (Minh-Giang, 2019). These amounts are considerable when the average salary of faculty members in the public sector ranges from about 151 USD to 520 USD a month (Cao-Nguyen, 2019). Yet, whether this kind of award is popular among universities is still in question since most universities do not publicly share related information.

Additionally, the effectiveness of faculty's research-related rewards and their associated mechanisms are a matter of concern and in need of further exploration. Nguyen (2016) revealed that many participants are worried that some criteria used to assess the research performance of academics are too easy to meet and that the reward mechanisms can only distinguish those who do research from those who do not, while they fail to reflect the differences between good performers and average ones. The problem of lecturers "buying" publications in Vietnamese universities, to meet their job requirements or get a promotion or reward, is also attributable to the research-related reward mechanism (Dang-Nguyen, 2020).

\section{Research Committee}

Vietnam has not yet developed a unified national framework focused on ethical issues in research with the exception of medical research. There are no legal documents that mention these matters and no agency to deal with them except for the National Professorship Committee (Hoi dong Giao su Nha nuoc). However, this board only regulates professorial candidates. For individuals other than professional candidates in the context of higher education, the ethical issues in research that they face are mainly mentioned in the regulations for doctorate students (Pham, 2013), especially in Chapter $V$ of Regulations on Doctorate Enrollment and Training. For example, doctorate dissertations are required to properly cite and refer to sources of research results of other authors, if any (MOET, 2017).

At the institutional level, scientific councils (Hoi dong Khoa hoc truong), and academic boards (Hoi dong Dao tao) are present in almost all Vietnamese public higher education institutions as a part of their organizational structures (Salmi \& Pham, 2019). The university rector establishes this body to give academic advice on relevant matters in the institution. Article 19 of the Higher Education Law of 2012 also has regulations on the functions of this body including, for instance, creating guidelines on research and training exercises and developing research plans (National Assembly of Vietnam, 2012). At the departmental level, there are also faculty councils (Hoi dong Khoa). A faculty council represents the academic staff of a department and takes responsibility for academic matters including research and teaching. Although these academic councils work as counselling groups for 
the university leadership; however, as indicated by Pham (2017), their position is restricted to the point that it is uncommon for there to be any contradictory ideas between academic councils and the university leadership.

Besides academic councils within universities, a research office also plays the role of a unit that manages and supports research. The effectiveness of this type of office in supporting research activities in Vietnamese universities has not been revealed on a large scale. Nguyen and Meek (2016), when examining research in four key universities in Vietnam, however, uncovered that the role of the research office seems unclear. This kind of office fails to develop its functions to the fullest extent especially in the sense that it is operated as an "organizer" and a "controller" rather than as a "planner" and a "leader." There seems to be a lack of an effective system that can help research behaviors be standardized and formalized.

\section{Publications}

Some decades ago, no Vietnamese universities were recognized for their quality of teaching and research by any rankings of either top Asian universities or global universities (Vallely \& Wilkinson, 2008). Vallely and Wilkinson (2008) accentuated that higher education institutions in Vietnam are secluded from global flows of knowledge and greatly lack research publications. In this regard, Vietnam seems to linger a long way behind its Southeast and East Asian neighbors, and considerably further behind when contrasted with developed nations. Since the mid-2000s, thanks to the dissemination of information from some leading Vietnamese scientists who studied in Western countries and returned to work in Vietnam, Vietnamese scholars have become familiar with academic databases from Western nations, such as the Clarivate's Web of Science and Elsevier's Scopus (Pham, 2019; Trinh et al., 2020). Additionally, the international world-class university initiatives, which emphasize the number of publications in peer-reviewed journals, also contribute to increasing interest in publications among Vietnamese academics (Salmi \& Pham, 2019). The quantity of publications of universities is also on the rise due to new regulations for doctoral training. Since 2017, the utilization of peer-reviewed international journals in Vietnam shifted from optional to required in some cases when a doctoral student is required to have at least one paper published in a Scopus/Web of Science-indexed journal for graduation. Among various criteria, it is also required that a lecturer must have one paper, at minimum, to be published in this kind of journal as the first or corresponding author to be eligible for being a doctoral supervisor (MOET, 2017). In addition, policies on research benefits, especially on rewarding the appearance of articles in international journals, have contributed to an increase in publications by academics at Vietnamese universities. Banking University of Ho Chi Minh City, Ho Chi Minh City University of Technology and Education, and Ho Chi Minh City Open University found that increased financial rewards for articles in journals indexed in Scopus or Web of Science have increased the number of articles in such journals written by academics at their institutions (Minh-Giang, 2019).

Due to these changes, Vietnamese higher education institutions have gained considerable ground in expanding the number of research publications (Minh-Giang, 2019, 2021; Nguyen, 2020). During 2011-2019, Vietnam published 33,474 Web of Science-indexed English articles, achieving an average growth rate of $22 \%$ annually (Nguyen, 2020). The rise in the number of articles in Web of Science-indexed journals can also be seen from the list of authors rewarded for publishing articles in this type of journal by MOET. From 28 universities with a total of 1,718 articles published in 2018, the number grew to 34 universities with a total of 3,627 articles by 2020 (Han-Tran, 2019; MinhGiang, 2021). Publication growth is also evident in data on articles in Scopus-indexed journals from 2000 to 2019, as Figure 1 shows (Scimago, 2020). 
Figure 1. The number of works published by Vietnam as recorded in the Scopus-database for years 2000-2019

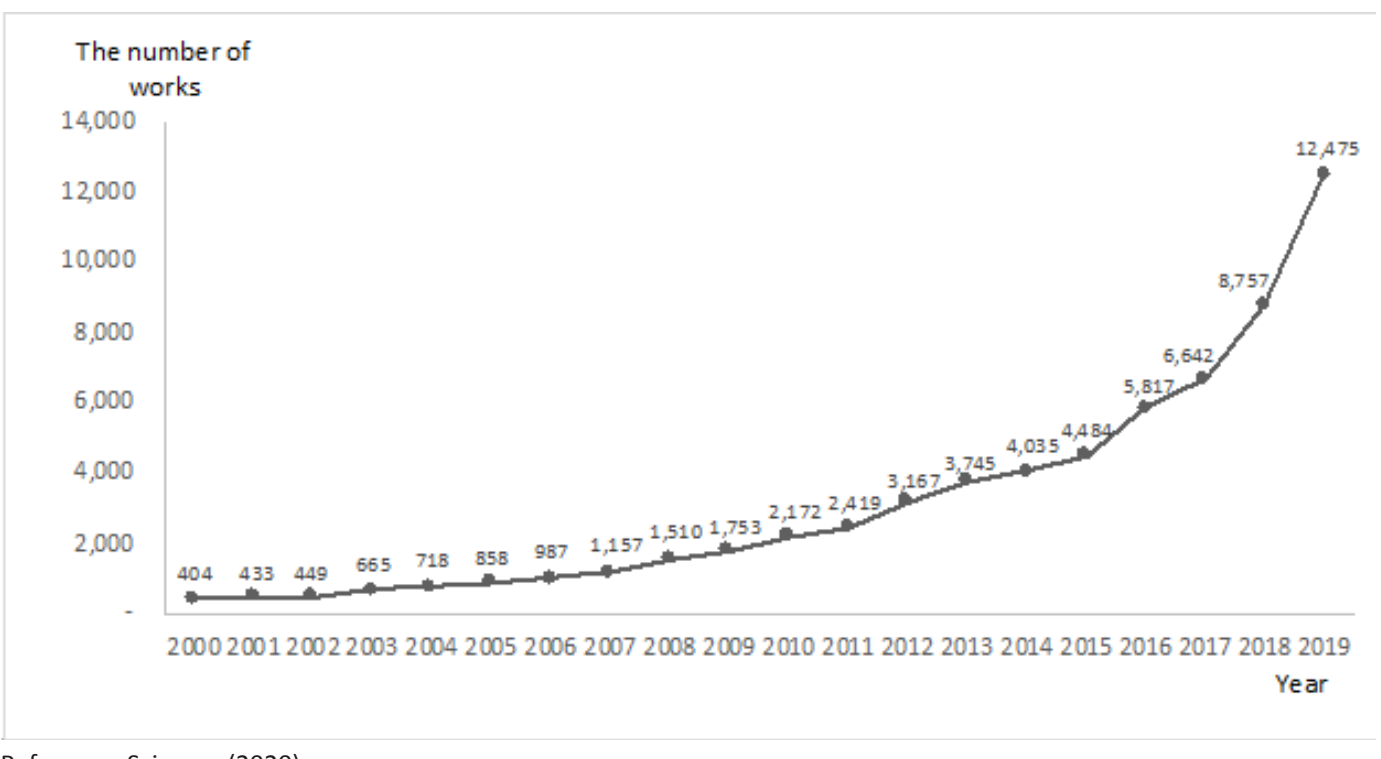

Reference: Scimago (2020)

As for the number of articles in various fields, academics from the natural and applied sciences, or science, technology, engineering and mathematics (STEM) subjects, have produced most of the publications. In contrast, papers in the social sciences and humanities are much lower (Le, 2016; Vuong \& Tran, 2019). The rate of publications produced by Vietnamese academics still varies greatly from one university to the next. From 2011 to 2019, only 66 (among more than 200 Vietnamese universities) had research published in Web of Science-indexed English journals, while the top ten universities in this list accounted for $50 \%$ of the total Web of Science-indexed English research output for the country (MOET, 2019; Nguyen, 2020). In terms of citations, despite a vast increase in research output in Vietnam in recent years, its number of citable records per 1 million citizens in 2017 was lower than the number in Indonesia, Malaysia, Singapore, and Thailand and only higher than that of the Philippines (World Bank, 2020a). It is also revealed that with regards to quality and effect as estimated by the $\mathrm{h}$-index, Vietnam was at the bottom of the list compared with other Southeast Asian countries, including Indonesia, Malaysia, the Philippines, Singapore, and Thailand (World Bank, 2020a).

\section{Discussion}

Research culture in Vietnamese universities has many characteristics, reflected through indicators compiled by Salazar-Clemeña and Almonte-Acosta (2007). Among factors contributing to the formation of research culture in Vietnamese universities are state-related ones, concerning what the government does toward education, and how. The state of Vietnam has issued many policies and legal documents for improving research in universities, to serve the development of the country after a period of economic and social stabilization following the war's end in 1975 (Nguyen, 2020), and to respond to the international world-class university initiatives that emphasize research and publications (Salmi \& Pham, 2019). State policies and regulations cover almost every aspect of university research, from human resources training to publications. Besides, the state has not stopped updating legal documents and issuing new ones. For example, the Amendment of Higher Education Law 2018 added provisions to prioritize the recruitment of lecturers with doctoral qualifications, as well as professors to promote research capabilities of universities, something 
that the 2012 Higher Education Law did not mention (National Assembly of Vietnam, 2012, 2018). Undeniably, the research culture of Vietnamese universities has changed due to the influence of these policies and documents. Many lecturers are allowed to study abroad in doctoral programs to improve their expertise; lecturers are rewarded for their research work, and collaboration with external partners gradually takes shape, mainly in relation to publications. However, some policies and documents related to university research remain inconsistent. For instance, the Amendment of Higher Education Law 2018 stipulates that universities have autonomy in academic aspects, but Article 42 of this Law still affirms that the government regulates science and technology activities in higher education institutions (National Assembly of Vietnam, 2018). In addition, several policies also lead to problems in research that are of public concern, such as those related to rewarding lecturers for having articles published in Scopus/Web of Science-indexed journals and using publications as one of the criteria for promoting and rewarding lecturers. This is something the state and other stakeholders must consider because it can create a "publish or perish" culture that threatens research ethics. Chasing articles for rankings, awards and promotions can cause institutions and individuals to violate ethical issues. Reportedly, some universities have paid fees to academics not affiliated with them for including their names as author- institutions in articles to increase the number of these "paying" institutions' publications, contributing to raising their rankings (Minh-Giang, 2019). This is considered as one of the "toxic" elements in academic culture, threatening the development of the country's higher education system (Yang, 2016).

In addition to rules and regulations, norms and traditions of the state for universities also contribute to features of the research culture in Vietnamese universities, such as university autonomy (Dao \& Hayden, 2015; Nguyen, 2020). Basically, autonomy for universities is no different from any other organization (Vo \& Laking, 2020). As Anderson and Johnson (1998) define it, autonomy is "the freedom of an institution to run its own affairs without direction or influence from any level of government" (p. 8). The autonomy of universities is distinguished by the aspect of academic freedom, which involves the right to determine the content, as well as methods, of its teaching and research (Vo \& Laking, 2020). The Vietnamese government has issued various policy documents that have further enhanced the autonomy of universities. Importantly, Resolution 77 allows universities to be fully self-financing instead of relying on state funding. Accordingly, universities are free to set and increase tuition fees within a limit set by the state and use these funds for their activities (Government of Vietnam, 2014). The Amendment of Higher Education Law 2018 also entitles the higher education institution to exercise autonomy in various aspects including academic and professional practice, organizational structure and personnel, and finance and property (National Assembly of Vietnam, 2018). Regardless of the government issuing policy documents to grant more autonomy to universities, various studies affirm that Vietnamese universities are still confronted with the lack of autonomy that has existed for a long time in the history of Vietnamese tertiary education (Dao \& Hayden, 2015; Le \& Hayden, 2017; Nguyen, 2020; World Bank, 2020a). Until now, there have been only 23 public higher education institutions (out of more than 170) that have experienced greater degrees of institutional autonomy, due to the "self-financing" mechanism. But to maintain self-financing status, universities must meet certain conditions, such as setting enrolment targets that comply with state regulations and setting aside at least $25 \%$ of revenues for their capital funds as well as complying with the tuition fee ceiling (Government of Vietnam, 2014). As a result, this mechanism does "little to increase universities' substantive academic or management autonomy," instead placing a heavier burden on students and their families, while removing the cost of the university from the state budget (Vo \& Laking, 2020, p. 1094). Salmi and Pham (2019) also shared similar ideas that the state has given higher education institutions more autonomy, but the autonomy granted to them is conditional, depending on capabilities and the results of their university rankings/accreditation. In other words, autonomy is still "a favor rather than a right" (p. 111). The lack of autonomy is said to hinder the introduction of financial rewarding measures for academics that have good achievements in their work since universities must comply with salary regulations based on the employment status of academics as they are doing (Nguyen, 2016). The 
use of universities' capital and assets in joint projects with external partners to raise money for their institutions is also challenging, as the process is subject to many complex regulations (Pham, 2020). The lack of autonomy certainly affects the general development of the research aspect of universities as autonomy is required for them in "charting their own paths to excellence" in research (Altbach \& Salmi, 2011, p. 27). Another point worthy of attention is that problems related to autonomy are also believed to come from the universities themselves. Financial resources are so weak and the management capacity of some university leaders is so limited that it is almost impossible to run universities as autonomous entities (MOET, 2020c). Also, university autonomy is governed not only by Higher Education Law but also by other laws, such as the Law on Public Property, the Law on Public Investment, the Law on State Budget, and the Law on Public Officials and Officers, some contents of which are not always aligned (Tran-Huynh, 2021).

Under the 2012 Higher Education Law, relevant line ministries or state agencies were responsible for the appointment of university rectors (National Assembly of Vietnam, 2012). However, Article 20 of the 2018 amendment to the law stipulates that rectors of public higher-education institutions are decided by university councils. Although this seems to give more autonomy to universities, the nominated candidate must be recognized by the "managing body of the university" (National Assembly of Vietnam, 2018). Hence the rector, appointed with the "assent" of the body that manages the institution (Vo \& Laking, 2020, p. 1084), is still granted nearly ultimate authority. Provided that the rector holds fast to MOET guidelines, or the directions given by other line ministries or state instrumentalities, this person can make decisions with little respect to the desires of other different stakeholders such as lecturers and students (Salmi \& Pham, 2019). For this reason, concerning research committees, although the Higher Education Law of 2012 provides room for academic councils to apply their leadership over a wide scope of scholarly issues, a large portion of their impact is in general limited to screening research proposals and to advising on the distribution of the university research funding (Salmi \& Pham, 2019). This is similar to the presence and operation of councils at departmental levels whose role is blurred. Most academic affairs related to departments are decided by the deans, and then the deans will report directly to the rector and vice versa. The rector, with almost absolute authority, usually assigns tasks to departments through the deans (Hayden \& Lam, 2006). With these characteristics, academic councils are unable to perform well in the function of advising or countering the university, but rather they turn into bodies that "counsel themselves" (Pham, 2017).

Various features of university research culture in Vietnam are also caused by the state's tradition of spending on higher education. Traditionally, Vietnam has spent less on higher education than on basic education and less on universities than on research institutes; these traditions have contributed to the paucity of financial resources available to fund research activities in universities (World Bank, 2019; Nguyen, 2020). Also, old norms are being used for subsidizing higher education, including the reality that many universities receive state funding based on historically-negotiated recurrent budget allocation - what they got in the past they will similarly get for the present and future. This creates several issues, including producing research results in the absence of standards of excellence or pertinence, as well as inadequate motivating forces to pull in extra wellsprings of financing from public-private associations and/or private credit markets (Dang, 2019; Thuy-Le, 2018). The absence of a tradition of establishing relationships with external partners causes various problems for research development in Vietnam including the low degree of research and technology transfer (Dang, 2019). Furthermore, the advancement of strong physical research infrastructure has been hindered by an absence of investment from industry in university research (Nguyen, 2013), which may also dissatisfy and disenchant qualified researchers (Weiler, Guri-Rosenblit \& Sawyerr, 2008). In addition, during a time when there are many obstacles to face-to-face group activities due to Covid-19, many universities in the world have turned to online platforms as a panacea for this situation to ensure the continuity of academic activities (Pokhrel \& Chhetri, 2021). However, with the current conditions related to the quality and quantity of the infrastructure, Vietnamese higher education institutions face many difficulties operating in this way (World Bank, 2020a). In this 
centralized management culture, researchers also appear to be "watched" too intently on how they utilize their research funding while there is a lack of clear and explicit guidance on the ways that research funding may be spent. To some extent, the close supervision helps in the management of funding, but it also gives the appearance that researchers are not trusted, which probably decreases innovation and contributes to the low levels of job satisfaction reported by scholars (Pham, 2013). Hence, this norm should be changed so that researchers can focus on doing research as their main task rather than having to spend too much time thinking about how to abide by rigid financial rules (Nguyen \& Meek, 2016).

\section{Conclusion}

State-related factors, such as policies and regulations for university research, as well as norms and traditions of the state for some aspects of university research, have contributed to the formation of various features in university research in Vietnam. The state has created many policies and legal documents that have been designed to improve university research. These are updated and changed as necessary to suit Vietnam's needs and respond to external influences. As a result, the research culture in Vietnamese universities has undeniably improved in recent years. Lecturers receive support to improve their qualifications; they are rewarded for their research works; the number of publications originating at Vietnamese universities has increased; and universities have begun to collaborate on research with external partners, including both individuals and organizations.

On the other hand, some of the government's policies and documents offer conflicting guidance. This makes it difficult and confusing for universities to institute policies that would promote research, such as improving salaries for faculty and using capital and assets in joint ventures (Pham, 2020). Additionally, the policies and regulations are often ineffective because there is little verification of whether universities implement them (MOET, 2020a). Besides, although various rules and regulations have been implemented to encourage the development of university research, some long-standing norms and traditions of the state for aspects of research have limited this improvement. These state-related factors include the nation's tradition of spending less on higher education than on basic education and less on universities than on research institutes independent of them, the lack of autonomy among universities, the almost ultimate power of the university rector, and the use of the historically-negotiated recurrent approach for allocating research funding to universities with too much supervision for researchers' use of funding. Different problems stem from these factors, such as the lack of budget for research and ethics-related matters. Although these staterelated factors cannot fully explain the existence of all the characteristics of the research culture of Vietnamese universities, the impact of these factors cannot be overshadowed, given the fact that Vietnam's higher education is highly regulated by the state, which has many different policies and legal documents covering almost all aspects of research. This reality ensures that changes to research culture in universities must accompany changes to the state-related factors believed to influence the formation of research culture's features.

To develop a research culture in Vietnamese universities, the state should develop more consistent regulations relating to the autonomy of universities and support universities in achieving autonomy. Besides, as a gap exists between the introduction of up-to-date policies or legal documents for research development at universities and the effectiveness of implementing them, the state must have a monitoring mechanism for the implementation of state policies and regulations, with content about recognizing successful cases and improving ineffective cases. The state also must adjust documents related to university research that perpetuate various inconsistencies. Issues related to research ethics also need attention through considering the provision of the guiding documents for universities and the establishment of an agency in charge of them. Greater state investment and encouragement of stakeholder participation are needed to develop the research infrastructure in Vietnam. The initial focus should be on universities that already have research-oriented personnel and policies. Also, the state should consider adopting different funding patterns, based on a range of 
strategic and competitive criteria such as performance funding, commonly used in the Netherlands and the United Kingdom and full-costing mechanisms for funding allocation, widely used in the United States, Australia, and the United Kingdom (Jongbloed, 2001; Dill \& van Vught, 2010). These adjustments are obviously challenging as some norms, beliefs, and traditions have existed for a long time and become deeply ingrained in individuals and organizations. Yet, the development of university research in Vietnam requires such changes.

\section{References}

Altbach, P. G., \& Salmi, J. (2011). The Road to Academic Excellence: The making of world-class research universities. Available at https://openknowledge.worldbank.org/bitstream/handl e/10986/2357/646680PUB0acad00Box361543B00PUBLIC0.pdf? sequence=1\&isAllowed=y [Accessed 18 February 2021].

Anderson, D., \& Johnson, R. (1998). University Autonomy in Twenty Countries. Canberra: Department of Employment, Education, Training and Youth Affairs.

Austin, A. E. (1990). Faculty cultures, faculty values. In W. G. Tierney (Ed.) New Directions for Institutional Research. San Francisco: Jossey-Bass, pp. 35-45. doi; 10.1002/ir.37019906807

Ca, T. N., \& Hung, N. V. (2011). Vietnam: Current debates on the transformation of academic institutions. In B. Göransson and C. Brundenius (Eds.) Universities in Transition. Insight and Innovation in International Development. New York: Springer-Verlag, pp.119-142. doi:10.1007/978-1-4419-7509-6_7

Cao-Nguyen. (2019). Chi tiet bang luong giao vien, giang vien thoi gian toi [Salaries of teachers and lecturers in the future]. Available at https://giaoduc.net.vn/giao-duc-24h/chi-tiet-bang-luonggiao-vien-giang-vien-thoi-gian-toi-post204831.gd [Accessed 15 July 2020] [in Vietnamese].

Center for Postsecondary Research. (2015). Carnegie Classification of Institutions of Higher Education. Bloomington: Indiana University School of Education.

Communist Party of Vietnam Online Newspaper. (2020). Hoan tang luong co so la can thiet [Delaying increasing average salaries is necessary]. Available at https://dangcongsan.vn/thoi-su/hoantang-luong-co-so-la-can-thiet-555336.html [Accessed 15 March 2021] [in Vietnamese].

Dang, T. (2019). The Need for Academic Reform in Vietnamese Higher Education (VHE) to Align with Employers' Expectations. Available at https://dune.une.edu/theses/210 [Accessed 12 May 2020].

Dang-Nguyen (2020). "Thi truong ngam" mua ban bai bao khoa hoc ["Black market" for scientific papers]. Available at https://thanhnien.vn/giao-duc/thi-truong-ngam-mua-ban-bai-bao-khoahoc-1265279.html [Accessed 22 February 2021] [in Vietnamese].

Dao, V. K., \& Hayden, M. (2015). Higher education governance reform in Vietnam. In K. M. Joshi and S. Paivandi (Eds.) Global Higher Education: Issues in Governance. Delhi: B. R. Publishing Corporation, pp. 315-338.

Deem, R., \& Lucas, L. (2007). Research and teaching cultures in two contrasting UK policy contexts: Academic life in education departments in five English and Scottish universities. Higher Education, 54(1), pp. 115-133. doi:10 1007/s10734-006-9010-z.

Dill, D. D., \& van Vught, F. A. (2010). National Innovation and the Academic Research Enterprise: Public Policy in Global Perspective. Baltimore, MD: Johns Hopkins University Press.

Fatseas, M. (2010). Research-industry cooperation supporting development in Vietnam: The challenge of translating policy into practice. In G. Harman, M. Hayden and T. N. Pham (Eds.) Reforming Higher Education in Vietnam. Netherlands: Springer, pp. 103-115. doi: 10.1007/978-90-4813694-0_7

Government of Vietnam. (2014). Nghi Quyet ve thi diem doi moi co che hoat dong doi voi cac co so giao duc dai hoc cong lap giai doan 2014-2017 [Resolution on piloting the renewed operational mechanism of public higher education institutions from 2014-2017]. Available at http://chinhphu. 
vn/portal/page/portal/chinhphu/hethongvanban?class_id=509\&mode=detail\&document_ id=177020 [Accessed 14 March 2021] [in Vietnamese].

Ha-Anh. (2019). Ngan sach cho nghien cuu thap hon dai hoc nuoc ngoai [Research budget in Vietnam is lower than that in other countries]. Available at https://thanhnien.vn/giao-duc/ngan-sachcho-nghien-cuu-thap-hon-dai-hoc-nuoc-ngoai-250-lan-1041554.html [Accessed 15 February 2021] [in Vietnamese].

Ha-Linh. (2020). Thuc day doanh nghiep dau tu cho nghien cuu va phat trien [Fostering investment in research and development from businesses]. Available at https://nhandan.com.vn/tin-tuckinh-te/thuc-day-doanh-nghiep-dau-tu-cho-nghien-cuu-va-phat-trien-449712/ [Accessed 15 February 2021] [in Vietnamese]. doi: 10.46223/HCMCOUJS.econ.vi.15.2.247.2020

Han-Tran. (2019). Bo GD-DT chi thuong toi thieu 2 trieu dong/bai bao khoa hoc quoc te [MOET allocates at least 2 million per one paper published in international journals]. Available at https://thanhnien.vn/giao-duc/bo-gd-dt-chi-thuong-toi-thieu-2-trieu-dongbai-bao-khoa-hocquoc-te-1100364.html [Accessed 25 February 2021] [in Vietnamese].

Harman, G., \& Nguyen, T. B. N. (2010). The research role of Vietnam's universities. In G. Harman, M. Hayden, and T. N. Pham (Eds.) Reforming Higher Education in Vietnam. Netherlands: Springer, pp. 87-102. doi: 10.1007/978-90-481-3694-0_6

Hayden, M., \& Lam, T. (2006). A 2020 vision for higher education in Vietnam. International Higher Education, 44(Summer), pp. 11-13. doi:10.6017/ihe.2006.44.7913.

Hernandez, M. E., \& Reyes, C. M. (2014). Research culture in higher education: The case of a foreign language department in Mexico. Profile Issues in Teachers' Professional Development, 16(2), pp. 135-150. doi:10.15446/profile.v16n2.40819.

Ho Chi Minh City International University (2021). Thong tin tuyen sinh [Admission information]. Available at https://oga.hcmiu.edu.vn/tuyensinh/ [Accessed 22 February 2021] [in Vietnamese].

Hofstede, G., Hofstede, G. J., \& Minkov, M. (2010). Cultures and Organizations: Software of the Mind. New York/London: McGraw-Hill.

Huang, F. (2018). What are the challenges facing the Asian academic profession? Available at https://apo.org.au/sites/default/files/resource-files/2018-01/apo-nid135086.pdf [Accessed 10 August 2020].

Hurtado, S., Alvarez, C. L., Guillermo-Wann, C., Cuellar, M., \& Arellano, L. (2012). A model for diverse learning environments: The scholarship on creating and assessing conditions for student success. In J. C. Smart and M. B. Paulsen (Eds.) Higher Education: Handbook of Theory and Research. Netherlands: Springer, pp. 41-122. doi: 10.1007/978-94-007-2950-6_2

Jongbloed, B. (2001). Performance-based Funding in Higher Education: An international survey. Available at https://bridges.monash.edu/articles/journal_contribution/Performance-based_ funding_in_higher_education_an_international_survey/4234334 [Accessed 14 March 2021].

Kunnari, I., Tien, H. T. H., \& Nguyen, T. L. (2019). Rethinking Learning Towards Education 4.0. Available at https://unlimited.hamk.fi/ammatillinen-osaaminen-ja-opetus/rethinking-learningeducation-4-0 [Accessed 22 February 2021].

Lacatus, M. (2013). Organizational culture in contemporary university. Procedia - Social and Behavioral Sciences, 76(2013), pp. 421-425. doi:10.1016/j.sbspro.2013.04.139.

Le, P. (2015). Co so vat chat ky thuat phuc vu nghien cuu va dao tao dai hoc con yeu kem [Facilities and infrastructure for research in training in universities are weak]. Available at https://dantri. com.vn/giao-duc-huong-nghiep/co-so-vat-chat-ky-thuat-phuc-vu-nghien-cuu-va-dao-tao-dhcon-yeu-kem-20151106222348355.htm [Accessed 15 February 2021] [in Vietnamese].

Le, T. K. A. (2016). Developing the academy in Vietnam: An investigation of the formation of academic identity by university lecturers in Vietnam. Unpublished Doctoral Dissertation. Southern Cross University.

Le, T. K. A., \& Hayden, M. (2017). The Road ahead for the higher education sector in Vietnam. Journal of International and Comparative Education, 6(2), pp. 77-89. doi:10.14425/jice.2017.6.2.77. 
London, J. (2011). Education in Vietnam. Singapore: Institute of Southest Asian Studies. doi: $10.1355 / 9789814279062$

Minh-Giang. (2019). Bai bao cong bo quoc te: Khoi sac nho thuong "khung" [Papers in international journals: Growing due to "giant" rewards]. Available at https://tuoitre.vn/bai-bao-cong-boquoc-te-khoi-sac-nho-thuong-khung-20191230204248167.htm [Accessed 22 September 2020] [in Vietnamese].

Minh-Giang. (2021). Gan 11 ti dong khen thuong bai bao khoa hoc quoc te nam 2020 [About 11 billion spent for rewarding papers in international journals in 2020]. Available at https://tuoitre. vn/gan-11-ti-dong-khen-thuong-bai-bao-khoa-hoc-quoc-te-nam-2020-20210113151942728.htm [Accessed 25 February 2021] [in Vietnamese].

Morgan, G. (2006). Images of Organization. New Delhi: Sage Publication.

National Assembly of Vietnam. (2012). Luat Giao duc Dai hoc [The 2012 Higher Education Law]. Available at http://vanban.chinhphu.vn/portal/page/portal/chinhphu/hethongvanban?class_ $i d=1 \&$ page $=1 \&$ mode $=$ detail\&document_id=163054 [Accessed 10 August 2020] [in Vietnamese].

National Assembly of Vietnam. (2013). Luat Khoa hoc va Cong nghe [The 2013 Law on Science and Technology]. Available at https://thuvienphapluat.vn/van-ban/cong-nghe-thong-tin/Luat-khoahoc-va-cong-nghe-nam-2013-197387.aspx [Accessed 22 September 2020] [in Vietnamese].

National Assembly of Vietnam. (2018). Nghị quyết số 34/2018/QH14 luật sửa đổi, bổ sung một số điều của luật giáo dục đại học [Decree no 34/2018/QH14 on changing and adding some articles from Higher Education Law, issued on 18/6/2012]. Available at https://thuvienphapluat.vn/ van-ban/giao-duc/Luat-Giao-duc-dai-hoc-sua-doi-388254.aspx [Accessed 15 Sept 2019] [in Vietnamese].

National Assembly of Vietnam. (2019). Nghi quyet so 86/2019/QH14 ve du toan ngan sach nha nuoc nam 2020 [Decree no 86/2019/QH14 on State budget estimate 2020]. Available at https:// thuvienphapluat.vn/van-ban/Tai-chinh-nha-nuoc/Nghi-quyet-86-2019-QH14-du-toan-ngansach-nha-nuoc-nam-2020-429560.aspx [Accessed 30 March 2021] [in Vietnamese].

Ngo, T. T. H. \& Pham, T. L. A. (2019). Thao go kho khan trong nghien cuu khoa hoc tai cac truong dai hoc Vietnam [To remove difficulties in scientific research at Vitnam universities]. Available at https://tapchitaichinh.vn/nghien-cuu-trao-doi/thao-go-kho-khan-trong-nghien-cuu-khoahoc-tai-cac-truong-dai-hoc-viet-nam-302883.html [Accessed 10 March 2021] [in Vietnamese].

Nguyen, T. L. H. (2013). The challenges of developing research resources for leading Vietnamese universities. Higher Education Management and Policy, 24(2), pp. 115-130. doi:10.1787/ hemp-24-5k3w5pdwd7g4.

Nguyen, T. L. H. (2016). Building human resources management capacity for university research: The case at four leading Vietnamese universities. Higher Education, 71(2), pp. 231-251. doi:10.1007/s10734-015-9898-2.

Nguyen, T. L. H. (2020). A review of university research development in Vietnam from 1986 to 2019. In L. H. Phan and B. N. Doan (Eds.) Higher Education in Market-oriented Socialist Vietnam: New Players, Discourses, and Practices. Cham: Palgrave Macmillan, pp. 63-86. doi: 10.1007/9783-030-46912-2_4

Nguyen, T. V., Ho-Le, T. P., \& Le, U. V. (2017). International collaboration in scientific research in Vietnam: An analysis of patterns and impact. Scientometrics, 110(2), pp. 1035-1051. doi: 10.1007/s11192-016-2201-1.

Nguyen, H., \& Meek, V. (2016). Key problems in organizing and structuring university research in Vietnam: The lack of an effective research "behaviour formalization" system. Minerva, 54(1), pp. 45-73. doi:10.1007/s11024-016-9289-6.

Nguyen, T. H. T., Tran, T., Dau, T. T., Nguyen, T. S. H., Nguyen, T. H., \& Ho, M. T. (2020). How scientific research changes the Vietnamese higher education landscape: Evidence from social sciences and humanities between 2008 and 2019. F1000Research, 9(152), pp. 1-11. doi:10.12688/ f1000research.21790.1. 
Pham, H. H. (2018). Dai hoc "bon cham khong" ["4.0" Universities]. Available at http://antgct.cand. com.vn/Nguoi-trong-cuoc/Dai-hoc-bon-cham-khong-517499/ [Accessed 18 September 2020] [in Vietnamese].

Pham, H. H. (2019). Sử dụng công cụ đo lường khoa học (bibliometrics) trong ngành toán tai Việt Nam. Using scientific measurement tools (bibliometrics) in mathematical science in Vietnam. Availabe at http://rpe.phuxuan.edu.vn/phong-van-gs-ngo- viet-trung-ve-viec-su-dung-congcu-do-luong-khoa-hoc-bibliometrics- trong-nganh-toan-tai-viet-nam/ [Accessed 14 March 2021] [in Vietnamese].

Pham, T. L. (2013). Case study: The effectiveness of research and innovation management at policy and institutional levels in Vietnam. In A. Olsson and L. Meek (Eds.) Effectiveness of Research and Innovation Management at Policy and Institutional Levels in Cambodia, Malaysia, Thailand and Vietnam. Paris: OECD, pp. 140-162.

Pham, T. L. (2017). Hoi dong khoa hoc truong dai hoc: Vi sao vai tro mo nhat? [Academic councils in universities: Why are they so invisible?]. Available at https://tiasang.com.vn/-giao-duc/HDKHtruong-dai-hoc-Vi-sao-vai-tro-mo-nhat--10500 [Accessed 17 September 2020] [in Vietnamese].

Pham, T. N. (2010). The higher education reform agenda: A vision for 2020. In G. Harman, M. Hayden, and T. N. Pham (Eds.) Reforming Higher Education in Vietnam: Challenges and Priorities: Higher Education Dynamics. Dordrecht, the Netherlands: Springer, pp. 51-64. doi: 10.1007/978-90481-3694-0_4

Pham, V. T. (2020). Tai chinh cho cac truong dai hoc cong lap khi thuc hien co che tu chu [Finance for public universities when they are granted with autonomy]. Available at https://tapchitaichinh. $\mathrm{vn} /$ nghien-cuu-trao-doi/tai-chinh-cho-cac-truong-dai-hoc-cong-lap-khi-thuc-hien-co-che-tuchu-318052.html [Accessed 14 March 2021] [in Vietnamese].

Pham, L. T., \& Hayden, M. (2019). Research in Vietnam: The experience of the humanities and social sciences. Journal of International and Comparative Education, 8(1), pp. 27-40. doi:10.14425/ jice.2019.8.1.27.

Pham,T. H., \& Nguyen, H. C. (2020). Academic staff quality and the role of quality assurance mechanisms: The Vietnamese case. Quality in Higher Education, 26(3), pp. 262-283. doi:10. 1080/13538322.2020.1761603.

Pham-Nghia \& Quang-Duc. (2020). Tang chi ngan sach cho giao duc dao tao va khoa hoc cong nghe [Increase budget spending on education, training and science and technology]. Available at http://dbndhatinh.vn/dbnd/portal/folder/ky-hop-quoc-hoi-16/news/tang-chi-ngan-sach-chogiao-duc-dao-tao-va-khoa-hoc-cong-nghe.html [Accessed 10 March 2021] [in Vietnamese].

Pokhrel, S. \& Chhetri, R. A. (2021). Literature review on impact of COVID-19 pandemic on teaching and learning. Higher Education for the Future, 8(1), pp. 133-141. doi:10.1177/2347631120983481.

Ribeiro, L. C., Rapini, M. S., Silva, L. A., \& Albuquerque, E. M. (2018). Growth patterns of the network of international collaboration in science. Scientometrics, 114(1), pp. 159-179. doi:10.1007/ s11192-017-2573-x.

Robbins, S., \& Judge, T. (2006). Organizational Behavior. San Diego: Prentice Hall.

Salazar-Clemeña, R. M., \& Almonte-Acosta, S. A. (2007). Developing Research Culture in Philippine Higher Education Institutions: Perspectives of university faculty. Available at http://unesdoc. unesco.org/images/0015/001578/157869e.pdf [Accessed 28 May 2020].

Salmi, J., \& Pham, L. T. (2019). Academic governance and leadership in Vietnam: Trends and challenges. Journal of International and Comparative Education, 8(2), pp. 103-118. doi:10.14425/jice.2019.8.2.103.

Sanyal, B. C., \& Varghese, N. V. (2006). Research Capacity in Higher Education Sector in Developing Countries. UNESCO: Paris.

Schein, E. H. (2010). Organizational Culture and Leadership. San Francisco, CA: Jossey-Bass.

Scimago. (2020). Country Rankings. Available at https://www.scimagojr.com/countryrank.php [Accessed 23 February 2021]. 
Smerek, R. E. (2010). Cultural perspectives of academia: Toward a model of cultural complexity. In J. C. Smart (Ed.) Higher education: Handbook of Theory and Research. Netherlands: Springer: Science+Business, pp. 381-423. doi: 10.1007/978-90-481-8598-6_10

Smith, P., Dugan, S., Trompenaars, F. (1996). National culture and the values of organizational employees - A dimensional analysis across 43 nations. Journal of Cross-cultural Psychology, 27(2), pp. 231-64. doi:10.1177/0022022196272006.

Spoo, R.. \& Dao, A. T. (2010). Intellectual property and Vietnam's higher education system. In G. Harman, M. Hayden, and P. T. Nghi (Eds.) Reforming Higher Education in Vietnam: Challenges and Priorities. Dordrecht, the Netherlands: Springer, pp.117-128. doi: 10.1007/978-90-4813694-0_8

Steenkamp, J. (2001). The role of national culture in international marketing research. International Marketing Review, 18(1), pp. 30-44. doi:10.1108/02651330110381970.

The Ministry of Education and Training (MOET). (2017). Circular 08/2017/TT-BGDĐT. Regulation on doctorate enrollment and training. Available at

https://en.naric.edu.vn/static/files/Document/08-2017-TT-BGD\%C4\%90T.pdf [Accessed 15 September 2020].

The Ministry of Education and Training (MOET). (2019). So lieu thong ke giao duc dai hoc nam hoc 2017-2018 [Statistics on higher education in the academic year 2017-2018]. Available at https://moet.gov.vn/thong-ke/Pages/thong-ko-giao-duc-dai-hoc.aspx?ltemID=5877 [Accessed 10 June 2020] [in Vietnamese].

The Ministry of Education and Training (MOET). (2020a). Khai mo "diem nghen" tu chinh sach den thuc tien tu chu dai hoc [Open the "bottleneck" from university autonomy policy to practice]. Available at https://moet.gov.vn/giaoducquocdan/giao-duc-dai-hoc/Pages/default. aspx?ItemID=7095 [Accessed 14 March 2021] [in Vietnamese].

The Ministry of Education and Training (MOET). (2020b). Thong tu quy dinh ma so, tieu chuan chuc danh nghe nghiep, bo nhiem va xep luong doi voi vien chuc giang day trong cac co so giao duc dai hoc cong lap [Circular 40/2020/TT-BGDDT by the Ministry of Education and Training: Codes, professional title standards, appointment and salary rating for teaching staff in public higher education institutions]. Available at https://luatvietnam.vn/giao-duc/thong-tu-40-2020xep-luong-vien-chuc-giang-day-trong-dai-hoc-cong-lap-192983-d1.html [Accessed 14 March 2021] [in Vietnamese].

The Ministry of Education and Training (MOET). (2020c). Tu chu trong giao duc dai hoc: Thuc trang, kho khan va giai phap [Autonomy in education: Current situations, challenges and solutions] Available at https://moet.gov.vn/giaoducquocdan/giao-duc-dai-hoc/Pages/default. aspx?ItemID=7082 [Accessed 14 March 2021] [in Vietnamese].

The Ministry of Science and Technology. (2008). Quyet dinh ban hanh quy che to chuc va hoat dong cua phong thi nghiem trong diem [Decision 08/2008/QÐ-BKHCN by the Ministry of Science and Technology: Promulgating the regulations on organization and operation of the key laboratories]. Availale at https://thuvienphapluat.vn/van-ban/Bo-may-hanh-chinh/Quyet-dinh08-2008-QD-BKHCN-Quy-che-to-chuc-va-hoat-dong-cua-phong-thi-nghiem-trong-diem-68604. aspx [Accessed 14 March 2021] [in Vietnamese].

The Prime Minister of Government. (2002). Quyet dinh ve viec phe duyet de an "Dao tao can bo khoa hoc, ky thuat tai cac co so nuoc ngoai bang ngan sach nha nuoc" [Decision on approving the project on "Training scientific and technical cadres at foreign establishments with the state budge]. Available at https://thuvienphapluat.vn/van-ban/Tai-chinh-nha-nuoc/Quyet-dinh-3222000-QD-TTg-De-an-Dao-tao-can-bo-khoa-hoc-ky-thuat-tai-nuoc-ngoai-bang-ngan-sach-nhanuoc-8543.aspx [Accessed 22 February 2021] [in Vietnamese].

The Prime Minister of Government. (2010). Quyet dinh phe duyet de an dao tao giang vien co trinh do trien si cho cac truong dai hoc, cao dang giai doan 2010-2010 [Decision on approving the scheme on doctoral training for university and college lecturers during 2010-2020]. Available 
at https://vanbanphapluat.co/decision-no-911-qd-ttg-approving-the-scheme-on-doctoraltraining-for-university [Accessed 22 February 2021] [in Vietnamese].

The Prime Minister of Government. (2014). Nghi dinh quy dinh viec dau tu phat trien tiem luc va khuyen khich hoat dong khoa hoc va cong nghe trong cac co so giao duc dai hoc [Decree about investing in developing the potential of universities and encouraging research and technology activities in universities]. Available at https://thuvienphapluat.vn/van-ban/dau-tu/nghi-dinh99-2014-nd-cp-dau-tu-phat-trien-tiem-luc-khuyen-khich-khoa-hoc-cong-nghe-co-so-giao-ducdai-hoc-255274.aspx [Accessed 10 August 2020] [in Vietnamese].

The Prime Minister of Government. (2019). Quyet dinh phe duyet de an nang cao nang luc doi ngu giang vien, can bo quan ly cac co so giao duc dai hoc dap ung yeu cau doi moi can ban toan dien giao duc va dao tao giai doan 2019-2030 [Decision 89/QĐ-TTg by the Prime Minister: Approving the Project on Enhancing the capabilities of Higher Education Institutions' leaders, managers, and lecturers to meet the demands of comprehensively innovating Vietnam's education and training in the period 2019-2030]. Available at https://thuvienphapluat.vn/van-ban/bo-mayhanh-chinh/Quyet-dinh-89-QD-TTg-2019-Nang-cao-nang-luc-giang-vien-can-bo-quan-ly-co-sogiao-duc-dai-hoc-405475.aspx [Accessed 14 November 2020] [in Vietnamese].

Thuy-Le. (2018). Ngan sach cho giao duc dai hoc can duoc phan bo theo don dat hang cua nha nuoc [Reseach budget for universities needs to be allocated based on the state's demands]. Available at http://baokiemtoannhanuoc.vn/giao-duc/ngan-sach-cho-giao-duc-dai-hoc-can-duoc-phanbo-theo-don-dat-hang-cua-nha-nuoc-140037 [Accessed 25 February 2021] [in Vietnamese].

Ton Duc Thang University (2021). Graduate admission. Available at https://admission.tdtu.edu.vn/ en/graduate/information/apply-for-scholarships [22 February 2021].

Tran, T. G., Mai, V. G., \& Luu, T. V. (2017). He thong quan ly thu vien phuc vu chien luoc dao tao chat luong cao tai truong dai học [Library management system serving high-quality training strategy at universities]. Tap chi Thu vien Viet Nam [Journal of Vietnamese Libraries], 5(2017), pp. 30-36.

Tran-Huynh. (2021). Tu chu dai hoc da co luat nhung vuong du thu [University autonomy is regulated but still faces different obstacles]. Available at https://tuoitre.vn/tu-chu-dai-hoc-da-co-luatnhung-vuong-du-thu-20201126211350175.htm [Accessed 25 February 2021] [in Vietnamese].

Trinh, T. P. T., Tran, T., Le, T. T. H., Nguyen, T. T., \& Pham, H. H. (2020). Factors impacting internationalindexed publishing among Vietnamese educational researchers. Learned Publishing, 33(4), pp. 419-429. doi:10.1002/leap.1323.

Trung, T., Thao, P. T. T., Cuong, M. L., Linh, K. H., \& Hiep, H. P. (2020). Research as a base for sustainable development of universities: Using the Delphi method to explore factors affecting international publishing among Vietnamese academic staff. Sustainability, 12(8), pp. 1-16. doi:10.3390/ su12083449.

UNESCO. (2014). Governance Reforms in Higher Education: A study of institutional autonomy in Asian countries. Available at https://unesdoc.unesco.org/ark:/48223/pf0000227242 [Accessed 9 June 2020].

Vallely, T. J., \& Wilkinson, B. (2008). Vietnamese Higher Education: Crisis and Response (Memorandum, Higher Education Task Force). Cambridge, MA: Harvard Kennedy School.

Vo, M. T. H., \& Laking, R. (2020). An institutional study of autonomisation of public universities in Vietnam. Higher Education, 79(5), pp. 1079-1097. doi:10.1007/s10734-019-00457-6.

Vuong, Q. H., \& Tran, T. (2019). The Vietnamese Social Sciences at a Fork in the Road. Warsaw: Sciendo. doi: 10.2478/9783110686081

Weiler, H. N., Guri-Rosenblit, S., \& Sawyerr, A. (2008). Universities as centres of research and knowledge creation: An endangered species? A summary report. In H. Vessuri and U. Teichler (Eds.) Universities as Centres of Research and Knowledge Creation: An Endangered Species? (Global Perspectives on Higher Education). Rotterdam/Taipei: Sense Publishers, pp. 15-32. doi: 10.1163/9789087904807_003

World Bank. (2019). Vietnam National University Development Project (P166656) - Project information document/Integrated safeguards data sheet (PID/ISDS). Available at http://documents1. 
worldbank.org/curated/en/459571551067350328/pdf/Concept-Project-InformationDocument-Integrated-Safeguards-Data-Sheet-Vietnam-National-University-DevelopmentProject-P166656.pdf [Accessed 14 March 2021].

World Bank. (2020a). Improving the Performance of Higher Education in Vietnam. Available at https:// elibrary.worldbank.org/doi/abs/10.1596/33681 [Accessed 22 July 2020].

World Bank. (2020b). Vietnam: New WB support for higher education and urban development. Available at https://www.worldbank.org/en/news/press-release/2020/06/30/vietnam-newwb-support-for-higher-education-and-urban-development [Accessed 14 March 2021].

Yang, R. (2016). Cultural challenges facing East Asian higher education: A preliminary assessment. In C. Collins, J. Hawkins, M. Lee and D. Neubauer (Eds.) The Palgrave Handbook of Asia Pacific Higher Education. New York: Palgrave Macmillan, pp. 227-245. doi: 10.1057/978-1-137-48739-1_16

Zha, Q. \& Shen, W. (2018). The paradox of academic freedom in the Chinese context. History of Education Quarterly, 58(3), pp. 447-452. doi:10.1017/heq.2018.22. 